\title{
Kajian Teknis Dan Ekonomis Penerapan Sistem Hibrid BAPV-PLN Pada Gedung Politeknik Aceh
}

\author{
Rachmad Ikhsan \\ Politeknik Aceh \\ Jln. Politeknik Aceh, Desa Pango Raya, Kec. Ulee Kareng, Kota Banda Aceh, 23119 \\ rachmad.ikhsan@politeknikaceh.ac.id
}

\begin{abstract}
Abstrak - Potensi radiasi matahari yang cukup besar (rata-rata 4,65 $\mathrm{kWh} / \mathrm{m}^{2} / \mathrm{hari}$ ) di wilayah Banda Aceh dapat dimanfaatkan untuk membangun sistem hibrid BAPV (Building Applied Photovoltaic)-PLN. Namun, penerapan sistem konversi energi surya menjadi energi listrik kurang berkembang di Aceh. Kondisi ini disebabkan oleh harga teknologi modul surya masih dianggap mahal bagi masyarakat. Studi ini juga melakukan kajian secara teknis dan ekonomis dari sistem BAPV yang diterapkan. Kajian teknis yang digunakan bertujuan menentukan apakah jumlah energi yang dihasilkan oleh sistem BAPV dapat memenuhi jumlah beban listrik pada Gedung Politeknik Aceh. Sementara kajian ekonomis bertujuan memperkirakan biaya investasi yang diperlukan untuk menerapkan sistem BAPV dan menentukan kapan sistem BAPV bernilai ekonomis. Metode yang digunakan pada kajian teknis yaitu perhitungan secara teori, sedangkan metode yang digunakan untuk kajian ekonomis adalah metode Life Cycle Cost. Dari hasil kajian teknis, energi yang dihasilkan oleh sistem BAPV ini dapat memenuhi kebutuhan energi listrik tahunan dengan surplus energi sebesar $6.017 \mathrm{kWh} / \mathrm{tahun}$. Dari hasil kajian ekonomis, sistem ini bernilai ekonomis karena memiliki nilai NPV (Net Present Value) sebesar Rp. 1.310.803.600 dan nilai PP (Payback Periode) selama 14 Tahun. Berdasarkan kajian teknis dan ekonomis dapat disimpulkan penerapan sistem hibrid BAPV-PLN ini dapat dilaksanakan karena bernilai ekonomis.
\end{abstract}

Kata kunci: BAPV, hibrid, kajian teknis, kajian ekonomis

Abstract - The solar radiation (an average of $4.65 \mathrm{kWh} / \mathrm{m} 2 /$ day) in the Banda Aceh is potential to be utilized to build a BAPV (Building Applied Photovoltaic) hybrid system. However, the implementation of solar energy conversion system into electrical energy in Aceh is still undeveloped. This happened because the price of solar module technology is still considered expensive for the community. This study also conducts technical and economic studies of the applied BAPV system. The technical studies are used to determine whether the amount of energy generated by the BAPV system can meet the amount of electrical load at the Aceh Polytechnic Building. While the economic study is aimed to estimate the investment, costs required to implement the BAPV system and to determine when the BAPV system is economical. The method used in the technical study calculating theoretically while the method used for economic review is the life cycle analysis method. From the technical studies, energy generated by this BAPV system can meet the needs of annual electrical energy with an energy surplus of 6,017 kWh / year. Meanwhile, from the results of economic studies, this system is economical because it has a NPV (Net Present Value) of Rp. 1.310.803.600 and the PP (Payback Period) value for 14 Years. Based on those technical and economic studies, it can be concluded that the implementation of $B A P V-P L N$ hybrid system can be implemented because of its economic value.

Keyword : BAPV, hybrid, technical Studies, economical studies

\section{Pendahuluan}

Potensi radiasi matahari yang cukup besar (ratarata $4,65 \mathrm{kWh} / \mathrm{m}^{2} /$ hari) di wilayah Banda Aceh dapat dimanfaatkan untuk membangun sistem hibrid BAPV (Building Applied Photovoltaic)-PLN [1]. Namun, penerapan sistem konversi energi surya menjadi energi listrik kurang berkembang di Aceh. Kondisi ini disebabkan oleh harga teknologi modul surya masih dianggap mahal bagi masyarakat [2], untuk mengatasi permasalahan tersebut, perlu adanya kajian teknis dan ekonomis pada penerapan sistem BAPV. Kelebihan yang dimiliki oleh teknologi BAPV berupa tidak adanya kebisingan, tingkat polusi yang sangat minim, serta sumber energi yang selalu tersedia yaitu energi Matahari [3], maka sistem BAPV dapat dijadikan sebagai pembangkit alternatif dari energi fosil yang persedian sumber energinya semakin menurun tiap tahunnya[4].

Untuk melihat sistem tersebut dapat berjalan dengan optimal perlu dilakukan kajian teknis agar dapat dilihat besarnya energi yang dibutuhkan dan juga energi yang dapat dihasilkan oleh suatu sistem hibrid BAPV-PLN dalam melayani kebutuhan energi listrik pada Gedung Politeknik Aceh. Kajian ekonomis juga diperlukan agar dapat dilihat besarnya total biaya yang dibutuhkan serta untuk melihat lamanya waktu 
pengembalian modal awal pada penerapan sistem tersebut. Sehingga dari hal tersebut masyarakat dapat melihat nilai manfaat dalam penerapan sistem tersebut dan menjadi pertimbangan dalam menerapkan sistem hibrid BAPV-PLN. Bangunan yang digunakan sebagai kajian teknis ekonomis penerapan BAPV yaitu bangunan Gedung Politeknik Aceh dengan posisi penempatan modul surya pada posisi atap Gedung, posisi atap dipilih agar dapat maksimal untuk menangkap radiasi Matahari yang optimal [2], disisi lain bangunan Gedung Politeknik Aceh merupakan gedung tertinggi diantara bangunan sekitarnya yaitu 15 meter, sehingga rugi-rugi yang ditimbulkan oleh efek shading (efek bayangan) dari bangunan lain sangat minim. Beberapa penelitian terdahulu yang berkaitan dengan Life Cycle Cost penerapan photovoltaik, diantaranya [5], [6] dan [7], ada beberapa perbedaan dengan penelitian ini, dimana pada penelitian ini tidak hanya menghitung Life Cycle Cost, akan tetapi pada penelitian ini juga menghitung lamanya waktu pengembalian modal awal (payback periode) serta menghitung nilai bersih sekarang (Net Present Value) yang didapat pada penerapan sistem tersebut. Penelitian ini juga mengkaji sistem hibrid yang akan dibangun berdasarkan kondisi dari setiap sensor yang digunakan.

\section{Tinjauan Pustaka}

\subsection{Building Applied Photovoltaic (BAPV)}

BAPV merupakan bagian dari strategi untuk mengaplikasikan suatu modul surya menjadi bagian dari suatu bangunan [8]. Konsep BAPV sendiri merupakan suatu perpaduan antara nilai estetika, teknologi kontruksi, produksi energi dan aspek lingkungan [9]. Pada saat sekarang ini aplikasi BAPV dimasukkan ke dalam pembangunan Gedung sebagai pokok atau sumber tambahan daya listrik. Keunggulan ini membuat BAPV salah satu segmen yang tumbuh paling cepat dari industri modul surya [10].Salah satu contoh penggunaan BAPV pada Bangunan Gedung dapat dilihat pada Gambar 2.1 di bawah ini.

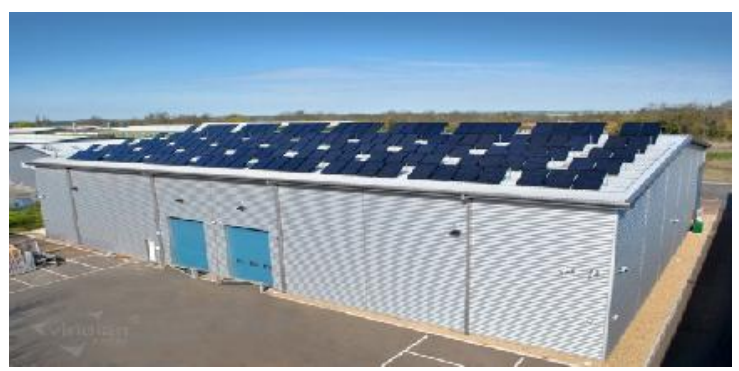

Gambar 2.1 Aplikasi BAPV Pada Atap Suatu Bangunan [11]

\subsection{Komponen BAPV}

Sistem BAPV secara keseluruhan terdiri dari komponen utama berupa $P V$ System dan komponen pendukung BAPV berupa baterai, inverter, charger controller [8].

a. Faktor Yang Mempengaruhi Energi Keluaran

Panel Surya

Untuk menentukan energi keluaran dari panel surya maka hal yang tidak kalah penting adalah mengetahui beberapa faktor yang dapat mempengaruhi energi keluaran panel surya, diantaranya yaitu [8] :

a. Intensitas Radiasi Matahari (Irradiance)

b. Spektrum (Spectrum)

c. Sudut Datang Sinar Matahari (Angle of Incidence)

d. Suhu (temperature)

e. Orientasi Panel Surya

f. Kecepatan Angin Bertiup

g. Keadaan Atmosfir Bumi

h. Bayangan (Shading)

\subsection{Sistem Hybrid BAPV-PLN}

Sistem hybrid merupakan integrasi antara dua atau lebih pembangkit listrik dengan sumber energi yang berbeda [12]. Pada penelitian ini integrasi pembangkit yang dipilih adalah pembangkit dari PLN dengan pembangkit dari sistem BAPV. Proses kendali sistem hybrid antara BAPV dan PLN dilakukan oleh unit kontroler. Dalam hal ini kontroller yang digunakan yaitu PLC (Programable Logic Controller). PLC dipilih sebagai pengatur atau unit kendali dalam menentukan pembangkit mana yang akan bekerja pada setiap kondisi. Selain PLC, komponen yang tidak kalah penting adalah ATS, secara sederhana fungsi ATS adalah untuk melakukan transfer daya secara otomatis ke beban, dari sebuah sumber utama (BAPV) ke sumber cadangan (PLN) ketika terjadi kekurangan daya pada sumber utama [13].

\subsection{Analisa Life Cycle Cost}

Analisa life cycle cost (LCC) merupakan salah satu metode yang ditawarkan dalam rangka penghitungan biaya yang lebih akurat dan lebih mendukung dalam pengambilan keputusan serta dapat diaplikasikan baik pada perusahan ataupun dalam menjalankan sebuah proyek [5]. Definisi Life Cycle Cost adalah biaya yang bersangkutan dengan produk selama daur hidupnya yang meliputi biaya pengembangan selama proses perancanaan, desain dan pengujian. Dalam melakukan analisa Life Cycle Cost dibutuhkan biaya-biaya yang relevan, antara lain biaya awal (present value), biaya operasional dan perawatan (maintenance), biaya energi, biaya penggantian, dan nilai sisa [5]. 


\subsection{Studi Kelayakan Bisnis}

Studi kelayakan bisnis pada dasarya bertujuan untuk menentukan kelayakan bisnis berdasarkan kriteria investasi [14].

Kriteria tersebut diantaranya adalah;

1. Nilai bersih kini (Net Present Value $=N P V$ )

2. Rasio manfaat biaya (Gross Benefit Cost Rasio $=$ Gross B/C)

3. Net Benefit Cost Rasio $=$ Net B/C)

4. Tingkat pengembalian internal (Internal Rate of Return $=I R R$ )

5. Profitability ratio $(\mathrm{PV} / \mathrm{K})$

6. Jangka waktu pengembalian modal investasi (Payback Period= PP)

\section{Metode Penelitian}

Metodologi penelitian yang digunakan adalah simulasi dan juga perhitungan secara teori. Objek yang dikaji adalah penerapan sistem hibrid BAPVPLN Gedung Politeknik Aceh di kota Banda Aceh.

\subsection{Teknik yang Digunakan}

Teknik yang digunakan untuk menyelesaikan permasalahan dan mendapatkan jawaban hasil penelitian yaitu dengan cara melakukan perhitungan secara teori untuk perhitungan energi yang dihasilkan dan proses perhitungan analisa biaya Life Cycle Cost dengan metode present worth (Nilai Sekarang) menggunakan software excell.

\subsection{Prosedur Penelitian}

Penelitian mengenai kajian teknis dan ekonomis penerapan sistem hibrid BAPV-PLN pada atap Gedung Politeknik Aceh dilakukan dengan prosedur sebagai berikut :

1. Mengestimasi kebutuhan energi dari data pemakaian energi listrik pada Gedung Politeknik Aceh.

2. Mengestimasi energi yang dihasilkan dengan tahapan :

a. Menghitung jumlah panel surya

b. Mencoba beberapa teknologi atau bahan sel surya

c. Menentukan posisi atau letak panel surya

d. Menghitung kapasitas baterai

Pada saat panel surya tidak bekerja maksimal akibat cuaca yang kurang baik, maka kebutuhan energi di ambil dari baterai, jika arus pada baterai tidak mencukupi, maka arus dari PLN yang akan disalurkan ke dalam sistem BAPV. Untuk lebih jelasnya dapat dilihat pada gambar 3.8.

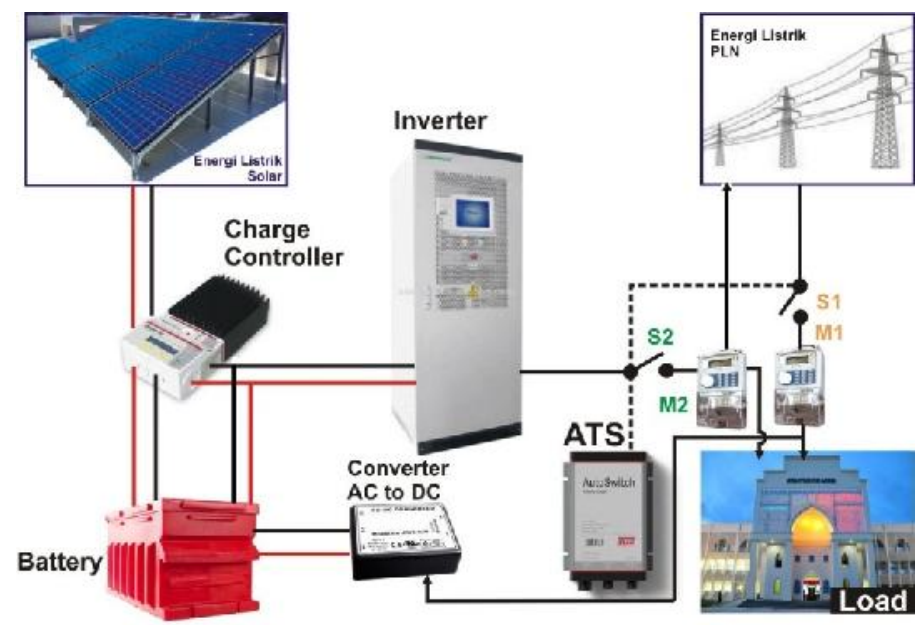

Gambar 3.1 Blok Diagram Sistem Kendali Hibrid BAPV-PLN Gedung Politeknik Aceh

Prinsip kerja blok diagram pada gambar 3.8 yaitu sistem kendali hibrid bekerja berdasarkan sensor tegangan pada panel surya dan sensor tegangan baterai. jika sensor 1 pada kondisi Off dan sensor 2 pada kondisi Off maka beban akan disuplai oleh PLN, selanjutnya PLN akan mencharging baterai. Jika sensor 1 pada kondisi Off dan sensor 2 On maka beban akan disuplai oleh baterai. Jika sensor 1 pada kondisi On dan Sensor 2 pada kondisi Off maka beban akan disuplai oleh BAPV dan melakukan proses charging, dan jika kedua sensor pada kondisi
On maka beban akan disupai oleh BAPV dan tidak melakukan proses charging. Apabila kondisi surplus energi, maka daya dari BAPV akan masuk ke jaringan PLN melalui inverter bi-directional.

e. Menghitung kapasitas charge controller

f. Menghitung kapasitas inverter

g. Menentukan sudut kemiringan panel pada posisi atap gedung

h. Menentukan Jenis Kabel

Dari data konsumsi energi listrik, didapatkan nilai tertinggi penggunaan energi listrik pada Gedung 
Politeknik Aceh terjadi pada bulan April tahun 2014 yaitu 609,3 kWh/hari. Akan tetapi karena sistem pembagian beban BAPV $=80 \%$ dan $\mathrm{PLN}=20 \%$, maka total beban yang ditangani oleh sistem BAPV menjadi 487,4 kWh/hari. Sehingga nilai daya yang dibutuhkan adalah :

$$
\begin{gathered}
P_{p}=\frac{L}{\eta_{c} x \eta_{b} x \eta_{i 1} x \eta_{c h a}} \\
P_{p}=\frac{487,4 k \quad h / h a}{95 \% x 95 \% x 96 \% x 95 \%} \\
P_{p}=444,5 k \quad h / h a
\end{gathered}
$$

Setelah $P_{p}$ didapatkan, maka selanjutnya adalah mencari total daya yang dihasilkan $\left(P_{\text {peak }}\right)$ :

$$
\begin{gathered}
P_{p}=\frac{P_{p}}{P} \\
P_{p}=\frac{444,5 \mathrm{k} h / \mathrm{ha}}{3,3 \mathrm{~h} / \mathrm{ha}} \\
P_{p}=134,7 \mathrm{k}
\end{gathered}
$$

Setelah $P_{\text {peak }}$ didapatkan, selanjutnya adalah menghitung jumlah panel surya, dikarenakan sistem tegangan yang digunakan adalah 12 Volt dan daya per panel surya adalah $P_{p m}=200 \mathrm{Wp}$, maka semua panel surya dihubungkan paralel, sehingga jumlah panel surya yang terhubung paralel adalah :

$$
\begin{gathered}
N_{p}=\frac{P_{p}}{P_{m}} \\
N_{p}=\frac{134,7 \mathrm{k}}{200 \mathrm{~W}} \\
N_{p}=674 \mathrm{~b} h
\end{gathered}
$$

Jika luas modul PV adalah $A_{m}=1,31 \mathrm{~m}^{2}$, maka luas area PV yaitu :

$$
\begin{gathered}
A=N_{p} \times A_{m} \\
A=674 b \quad h \times 1,31 m^{2} \\
A=882 m^{2}
\end{gathered}
$$

Setelah luas area PV didapatkan, selanjutnya adalah menghitung kapasitas baterai. Jika waktu penggunaan baterai maksimal 1 hari dan DOD (Depth of Discharge) atau tingkat kedalaman pengosongan baterai adalah $80 \%$, maka:

$$
\begin{aligned}
C_{b} & =\frac{N}{D \quad \eta_{b}} \\
C_{b} & =\frac{1 \times 487,4 k \quad h}{80 \% \times 95 \%} \\
C_{b} & =48236 \mathrm{Ah}
\end{aligned}
$$

$C_{b}$

$=129 b \quad h b \quad d \quad k c$ 375 Ah $12 \mathrm{~V}$

Setelah kapasitas baterai didapatkan, maka selanjutnya adalah menentukan kapasitas charger controller, dimana untuk mendapatkan kapasitas charger controller, harus mengetahui nilai Isc Panel Surya, yaitu Isc $=8,81 \mathrm{~A}$, sehingga kapasitas charger controller adalah :

$$
\begin{aligned}
C_{\text {cha }}=I_{S} & \times N_{p} \\
C_{\text {cha }}=8,81 A & \times 674 \mathrm{~b} \quad h p
\end{aligned}
$$

$C_{\text {cha }}$

$=5934 A a \quad 99 B \quad h$ Cha $C c \quad d$ $k p a$

Selanjutnya menentukan kapasitas inverter yang akan digunakan, yaitu :

$$
\begin{gathered}
C_{i 1}=V_{m} \quad x I_{m} \quad x N_{p} \\
C_{i 1}=25,3 \mathrm{~V} \quad 7,91 \mathrm{~A} 674 \mathrm{~b} \quad \mathrm{~h} \\
C_{i 1}=135 \mathrm{k}
\end{gathered}
$$

3. Menganalisa biaya melalui metode Life Cycle Cost

Nilai Life Cycle Cost didapatkan melalui perhitungan investasi sistem BAPV seperti biaya investasi awal meliputi biaya komponen BAPV, biaya pemasangan rak panel dan biaya instalasi sistem BAPV. Komponen biaya yang termasuk dalam sistem BAPV adalah pembelian panel surya, baterai, inverter, charge controller. Untuk biaya instalasi rak panel sudah dipaketkan untuk 1 panel surya dan terhitung juga biaya pengiriman komponen rak panel.

Tabel 3.1 Estimasi Biaya Awal (Initial Cost) Sistem Hibrid BAPV -PLN Gedung Politeknik Aceh

\begin{tabular}{|c|l|c|c|c|r|}
\hline No & \multicolumn{1}{|c|}{ Nama Peralatan } & Volume & Unit & $\begin{array}{c}\text { Unit } \\
\text { Biaya(Rp) }\end{array}$ & $\begin{array}{c}\text { Total Biaya } \\
\text { (Rp) }\end{array}$ \\
\hline 1 & Panel Surya 200 Wp & 674 & Buah & 4.125 .000 & 2.778 .408 .000 \\
\hline 2 & Inverter 135 kW Bidirectional & 1 & Buah & 520.990 .400 & 520.990 .400 \\
\hline 3 & Baterai 12 V 375 Ah & 129 & Buah & 6.538 .000 & 840.982 .940 \\
\hline 4 & ATS 220/380 V & 1 & Buah & 84.500 .000 & 84.500 .000 \\
\hline 5 & PLC Twido & 1 & Buah & 4.500 .000 & 4.500 .000 \\
\hline 6 & Sensor Tegangan 5 Volt & 2 & Buah & 50.000 & 100.000 \\
\hline 7 & Charger Controller Tri Star 60 & 99 & Buah & 15.925 .000 & 1.574 .984 .075 \\
\hline 8 & Kabel PV diameter 6 mm $^{2}$ & 882 & meter & 11.200 & 9.878 .152 \\
\hline
\end{tabular}




\begin{tabular}{|r|l|c|c|c|r|}
\hline 9 & Biaya Pengiriman & 1 & Paket & 16.000 .000 & 16.000 .000 \\
\hline 10 & $\begin{array}{l}\text { Biaya instalasi dan Setting } \\
\text { BAPV }\end{array}$ & 1 & Paket & 20.000 .000 & 20.000 .000 \\
\hline 11 & Rak Panel Surya & 674 & Buah & 470.000 & 316.570 .124 \\
\hline 12 & Biaya Instalasi rak panel surya & 1 & Paket & 10.000 .000 & 10.000 .000 \\
\hline 13 & Biaya pengiriman material & 1 & Paket & 1.000 .000 & 1.000 .000 \\
\hline & \multicolumn{2}{|r|}{ Total biaya awal } & & 6.177 .913 .691 \\
\hline & Total biaya Tanpa Baterai & 5.336 .930 .751 \\
\hline
\end{tabular}

Tabel 3.2 Nilai Sisa Peralatan Sistem Hibrid BAPV-PLN Pada Gedung Politeknik Aceh

\begin{tabular}{|c|l|r|r|r|r|}
\hline No & \multicolumn{1}{|c|}{ Nama peralatan } & \multicolumn{1}{|c|}{$\begin{array}{c}\text { Harga } \\
\text { Perolehan(Rp) }\end{array}$} & $\begin{array}{c}\text { Umur } \\
\text { Ekonomis }\end{array}$ & \multicolumn{1}{c|}{$\begin{array}{c}\text { Nilai Sisa } * \\
\text { (Rp) }\end{array}$} & \multicolumn{1}{c|}{$\begin{array}{c}\text { Depresiasi per } \\
\text { tahun (Rp) }\end{array}$} \\
\hline 1 & Panel Surya 200 Wp & 2.778 .408 .000 & 20 & 277.840 .800 & 125.028 .360 \\
\hline 2 & $\begin{array}{l}\text { Inverter bidirectional } \\
150 \mathrm{~kW}\end{array}$ & 520.990 .400 & 5 & 52.099 .040 & 93.778 .272 \\
\hline 3 & ATS 220/380 & 84.500 .000 & 5 & 8.450 .000 & 15.210 .000 \\
\hline 4 & Baterai 12 V 375 Ah & 840.982 .940 & 3 & 84.098 .294 & 252.294 .882 \\
\hline 5 & $\begin{array}{l}\text { PLC Twido } \\
\text { Schneider }\end{array}$ & 4.500 .000 & 5 & 450.000 & 810.000 \\
\hline 6 & Sensor Tegangan & 100.000 & 5 & 10.000 & 18.000 \\
\hline 7 & $\begin{array}{l}\text { Charge Controller Tri } \\
\text { Star 60 }\end{array}$ & 1.574 .984 .075 & 5 & 157.498 .408 & 283.497 .134 \\
\hline 8 & Kabel PV & 9.878 .152 & 10 & 987.815 & 889.034 \\
\hline 9 & Rak Panel Surya & 316.570 .124 & 20 & 31.657 .012 & 14.245 .656 \\
\hline & Total Nilai Sisa & 6.130 .913 .691 & & 613.091 .369 & 785.771 .337 \\
\hline
\end{tabular}

*kebijakan manajemen, nilai sisa dihitung $10 \%$ dari harga perolehan aset

4. Hasil dan Pembahasan

4.1 Hasil Kajian Teknis
Perbandingan antara energi yang dihasilkan dengan energi yang dibutuhkan terdapat pada gambar 4.1 .

Tabel 4.1 Rasio pembagian beban sistem hibrid BAPV-PLN

\begin{tabular}{|c|c|c|c|c|}
\hline$\%$ PV & $\begin{array}{c}\text { Kapasitas } \\
\text { PV }(\mathrm{kW})\end{array}$ & $\begin{array}{c}\text { Energi yang } \\
\text { dihasilkan BAPV } \\
\text { (kWh/hari) }\end{array}$ & $\begin{array}{c}\text { Energi yang } \\
\text { ditangani oleh } \\
\text { PLN (kWh/hari) }\end{array}$ & Total Biaya (Rp) \\
\hline 100 & 168,4 & 609,3 & 0 & 7.697 .367 .113 \\
\hline 90 & 152 & 548,4 & 60,9 & 6.937 .640 .402 \\
\hline 80 & 135 & 487,4 & 121,9 & 6.177 .913 .691 \\
\hline 70 & 118 & 426,5 & 182,8 & 5.418 .186 .979 \\
\hline 60 & 101 & 365,6 & 243,7 & 4.658 .460 .268 \\
\hline 50 & 84,2 & 304,7 & 304,7 & 3.575 .589 .557 \\
\hline
\end{tabular}




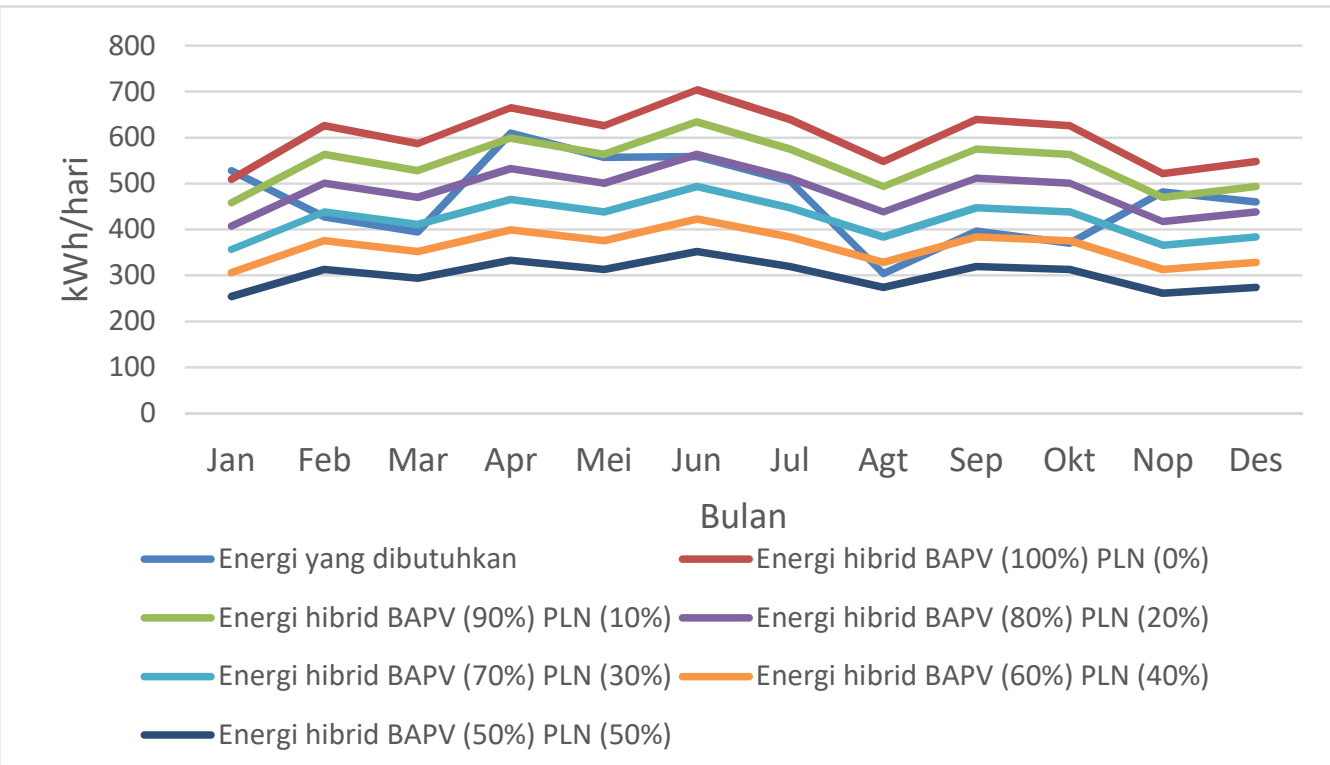

Gambar 4.1 Perbandingan energi yang dibutuhkan dengan energi yang dihasilkan oleh sistem hibrid BAPV-

PLN

Dari tabel 4.1 dapat dilihat bahwa total daya yang dihasilkan paling tinggi adalah $168,4 \mathrm{~kW}$, pembagian sistem hibrid $\mathrm{BAPV}=100 \%$ dan $\mathrm{PLN}=0 \%$, total biaya yang diperlukan, yaitu $\mathrm{Rp}$. 7.697.367.113. Apabila pembagian sistem hibrid $\mathrm{BAPV}=80 \%$ dan $\mathrm{PLN}=20 \%$, total daya yang hasilkan $135 \mathrm{~kW}$ dengan total biaya yang diperlukan yaitu $\mathrm{Rp}$. 6.177.913.691. Sedangkan total daya yang dihasilkan paling rendah adalah $84,2 \mathrm{~kW}$, pembagian sistem hibrid BAPV $=50 \%$ dan PLN $=50 \%$, total biaya yang diperlukan, yaitu Rp. 3.575.589.557.

Dari gambar 4.1 dapat dilihat bahwa energi yang dihasilkan paling optimum adalah energi dengan pembagian sistem hibrid $\mathrm{BAPV}=80 \%$ dan $\mathrm{PLN}=20 \%$, dikarenakan energi yang dihasilkan dari sistem tersebut tidak tinggi nilainya dan juga tidak rendah nilainya, total biaya yang diperlukan yaitu $\mathrm{Rp}$. 6.177.913.691. Defisit energi terjadi pada bulanbulan tertentu, seperti pada bulan Januari sebesar $121,3 \mathrm{kWh} / \mathrm{hari}$, bulan April sebesar $77 \mathrm{kWh} / \mathrm{hari}$, bulan Mei sebesar 56,4 kWh/hari, bulan Nopember sebesar 64,4 kWh/hari, dan bulan Desember sebesar $21,9 \mathrm{kWh} / \mathrm{hari}$. Pada bulan yang lain terdapat kelebihan energi (surplus energy) seperti pada bulan Februari sebesar 73,4 kWh/hari, bulan Maret sebesar $75,1 \mathrm{kWh} / \mathrm{hari}$, bulan Juni sebesar 4,3 kWh/hari, bulan Juli sebesar 6,2 kWh/hari, bulan Agustus sebesar 134,8 kWh/hari, bulan September sebesar $114,5 \mathrm{kWh} /$ hari dan bulan Oktober sebesar 130,8 $\mathrm{kWh} /$ hari. Energi yang dihasilkan oleh sistem hibrid BAPV-PLN yaitu $176.535 \mathrm{kWh} /$ tahun atau 490,37 $\mathrm{kWh} /$ hari dengan surplus energi sebesar 6.017 $\mathrm{kWh} /$ tahun.
Pemilihan teknologi bahan monocrystalline mengacu kepada data sheet bahan monocrystalline dan polycrystalline seperti tegangan Voc (Tegangan Open Circuit). Pada bahan monocrystalline tegangan Voc jauh lebih besar nilainya dibandingkan dengan bahan polycrystalline yaitu pada bahan jenis Mono Voc nya adalah 30,34 Volt DC, sedangkan pada bahan poly, Voc nya adalah 30,29 Volt DC. Selanjutnya jika dilihat pada efisiensi modul, bahan monocrystalline juga jauh lebih besar nilai efisiensinya dibandingkan dengan bahan jenis polycrystalline, jika pada bahan mono nilai efisiensinya adalah $15,27 \%$, maka pada bahan jenis poly, nilai efisiensinya adalah $14,51 \%$. Berat modul surya jenis poly juga jauh lebih berat dibandingkan dengan modul surya jenis Mono, yaitu pada modul poly beratnya adalah $15 \mathrm{Kg}$, sedangkan pada modul mono beratnya adalah $10,8 \mathrm{Kg}$. Semakin berat modul yang digunakan, maka semakin berkurang pula daya tahan bangunan untuk menopang modul surya tersebut.

Sudut kemiringan panel surya yang digunakan disesuaikan dengan posisi latitude dari Gedung Politeknik Aceh yaitu $5^{\circ}$, mengingat sudut $5^{\circ}$ terlalu landai yang dapat mengakibatkan terjadinya penumpukan kotoran debu dan juga efek panas yang ditimbulkan dari gedung serta kurang efektifnya dalam pemeliharaan secara natural (oleh air hujan), maka sudut kemiringan panel surya ditambah $20^{\circ}$, sehingga sudut yang digunakan dalam penerapan sistem hibrid BAPV-PLN menjadi $25^{\circ}$.

\subsection{Hasil Kajian Ekonomis}

Adapun hasil kajian ekonomis terbagi ke dalam dua macam yaitu analisa life cycle cost dan studi kelayakan. Untuk lebih jelasnya dapat dilihat pada 
sub bab di bawah ini.

\section{A. Analisa Life Cycle Cost}

Analisa Life Cycle Cost ini menggunakan pendekatan ekivalen metode nilai sekarang (Present Worth Method). Perhitungan besarnya Present Worth menggunakan biaya-biaya yang terdapat dalam Tabel 3.1 sampai dengan Tabel 3.4 yaitu dengan menggunakan :

a. Tingkat suku bunga (i) : $15 \%$

b. Periode analisa (n) : 20 tahun c. Present time / tahun ke - 0 : tahun 2016

d. Inflasi diabaikan

a. LCC Modelling

1. LCC Modelling Tanpa Nilai Sisa

Life Cycle Cost Modelling dibuat untuk memperlihatkan persentase dari tiap kategori biaya di dalam Life Cycle Cost [3]. Pada Sistem Hibrid BAPV-PLN Gedung Politeknik Aceh.

Tabel 4.2 Persentase LCC tiap Kategori Biaya

\begin{tabular}{|c|l|c|c|}
\hline No & \multicolumn{1}{|c|}{ Kategori Biaya } & LCC (Rp) & Percentase \\
\hline 1 & Biaya Awal & 6.177 .913 .691 & $66,62 \%$ \\
\hline 2 & Biaya Operasional dan Perawatan & 59.911 .396 & $0,65 \%$ \\
\hline 3 & Biaya Penggantian & 3.035 .935 .567 & $32,74 \%$ \\
\hline & Total LCC & 9.273 .760 .653 & $100 \%$ \\
\hline
\end{tabular}

2. LCC Modeling dengan Nilai Sisa

Jika memasukkan Nilai Sisa Peralatan dalam

Life Cycle Cost sistem hibrid BAPV-PLN Pada
Gedung Politeknik Aceh, maka persentase dari tiap kategori biaya berubah.

Tabel 4.3 Persentase Pada Setiap Kategori Biaya Dengan Memasukkan Nilai Sisa

\begin{tabular}{|c|l|r|c|}
\hline No & \multicolumn{1}{|c|}{ Kategori Biaya } & \multicolumn{1}{c|}{ LCC (Rp) } & Percentase \\
\hline 1 & Biaya Awal (Initial Cost) & 6.177 .913 .691 & $62,49 \%$ \\
\hline 2 & Biaya Operasional dan Perawatan (O/M Cost) & 59.911 .396 & $0,61 \%$ \\
\hline 3 & Biaya Penggantian (Replacement Cost) & 3.035 .935 .567 & $30,71 \%$ \\
\hline 4 & Nilai Sisa (Residual Cost) & 613.091 .369 & $6,20 \%$ \\
\hline & Total LCC & 8.660 .669 .284 & $100 \%$ \\
\hline
\end{tabular}

Dengan menggunakan Present Worth Method pada tingkat suku bunga $(\mathrm{i})=15 \%$ dan periode analisa (n) =20 tahun, total biaya hidup (Life Cycle Cost) dari Proyek Hibrid BAPV-PLN Gedung Politeknik Aceh adalah sebesar Rp. 9.934.458.110 dengan rincian sebagai beikut:

a. Initial Cost sebesar Rp. 6.177.913.691, Operational and Maintenance sebesar Rp. 59.911.396 dan Replacement Cost sebesar Rp. 3.035.935.567.

Pada LCC Modelling, dapat dilihat bahwa persentase tiap kategori biaya terhadap biaya total jika tanpa memperhitungkan nilai sisa, yaitu Initial Cost sebesar 66,62\%, Operational and Maintenance Cost sebesar 0,65\%, dan Replacement Cost sebesar $32,74 \%$, sedangkan jika memperhitungkan nilai sisa, maka persentase tiap kategori biaya berubah menjadi, yaitu Initial Cost sebesar 62,49\%, Operational and Maintenance Cost sebesar 0,61\%, Replacement Cost sebesar 30,71\%, dan Residual Cost sebesar 6,20\%. Dari LCC Modelling juga dapat diketahui bahwa dengan atau tanpa memperhitungkan nilai sisa, persentase terbesar dari Life Cycle Cost pada Proyek Hibrid BAPV-PLN Gedung Politeknik Aceh adalah Initial Cost.

\section{B. Studi Kelayakan}

Adapun studi kelayakan pada proyek sistem hibrid BAPV-PLN pada atap Gedung Politeknik Aceh, mengikuti ketentuan sebagai berikut :

\section{a. Penyusunan Cashflow}

Penyusunan cashflow menggunakan beberapa asumsi di antaranya :

- Tingkat Suku Bunga $=15 \%$

- Discount Factor $=20 \%$

- Umur ekonomis sistem BAPV = 20 Tahun

- Harga Jual Energi Listrik = 17 \$/kWh 
Tabel 4.4 Hasil Evaluasi Studi Kelayakan

\begin{tabular}{|c|c|c|c|}
\hline No & $\begin{array}{c}\text { Parameter } \\
\text { Evaluasi }\end{array}$ & $\begin{array}{c}\text { Hasil } \\
\text { Perhitungan }\end{array}$ & $\begin{array}{c}\text { Kriteria } \\
\text { Kelayakan } \\
\text { Proyek }\end{array}$ \\
\hline 1 & NPV & $\begin{array}{c}\text { Rp. } \\
1.310 .803 .600\end{array}$ & NPV $>0$ \\
\hline 2 & PP & 14 Tahun & $\begin{array}{c}\text { PP }<\text { Umur } \\
\text { Ekonomis } \\
\text { Proyek }\end{array}$ \\
\hline 3 & BCR & 0,94 & BCR $>0$ \\
\hline 4 & IRR & $17 \%$ & IRR $>0$ \\
\hline
\end{tabular}

Dari tabel 4.4 dapat dilihat bahwa, hasil perhitungan NPV yaitu Rp. 1.310.803.600 yang berarti proyek ini menguntungkan, sesuai dengan kriteria kelayakan proyek NPV >0 dan waktu pengembalian modal (Payback Periode) juga tidak melebihi umur ekonomis dari suatu pembangkit yaitu 14 Tahun. Rasio keuntungan antara biaya yang ditunjukkan oleh BCR merupakan angka yang positif yaitu 0,94 dan yang terakhir yaitu IRR yang diperoleh sebesar $17 \%$. Berdasarkan hasil evaluasi tersebut proyek sistem hibrid BAPV-PLN pada atap gedung Politeknik Aceh dapat direalisasikan karena memenuhi kriteria studi kelayakan

\section{Kesimpulan}

Adapun kesimpulan dari penelitian ini yaitu :

a. Dari hasil kajian teknis, diperoleh desain yang sesuai untuk penerapan sistem BAPV pada Gedung Politeknik Aceh, yaitu sistem dengan daya output yang dapat melayani $80 \%$ dari beban maksimum tahunan.

b. Hasil perhitungan kajian ekonomis didapatkan nilai NPV Rp. 1.310.803.600 dan lama waktu pengembalian modal awal (Payback Periode) 14 tahun, yang berarti proyek ini menguntungkan sesuai dengan kriteria kelayakan proyek NPV $>0$ dan Payback Periode tidak melebihi umur peralatan BAPV.

\section{Daftar Pustaka}

[1] I. D. Sara "Analisis Potensi Kondisi Suhu dan Radiasi Sinar Matahari di Kota Banda Aceh untuk Pengembangan Pembangkit Listrik Tenaga Surya." Seminar Nasional dan Expo Teknik Elektro (2014): 142-145.

[2] K. A. Joshi, N. M. Pindoriya. "Impact Investigation of Rooftop Solar PV System:A Case Study in India.” Innovative Smart Grid Technologies Europe, 2012. ISGT 2012. 3rd IEEE PES. 2012: 1-8.

[3] M. M. Rahman, L. K. Haur, H. Y. Rahman. "Building Integrated Photovoltaic (BIPV) in Malaysia: An Economic Feasibility Study."
Elixir Finance 45 (2012): 7683-7688.

[4] C. O. C. Oko, E.O. Diemuodeke, N.F. Omunakwe, E. Nnamdi. "Design and Economic Analysis of a Photovoltaic System: A Case Study." International Journal of Renewable Energy Development 3 (2012): 65-73.

[5] T. Firsani, C. Utomo. "Analisa Life Cycle Cost pada Green Building Diamond Building Malaysia." Jurnal Teknik ITS Vol. 1, No. 1, Sept. 2012.

[6] A. Q. Jakhrani, A. K. Othman, A. R. H. Rigit, S. R. Samo, L. P. Ling, R. Baini. "Cost Estimation of A Standalone Photovoltaic Power System in Remote Areas of Sarawak Malaysia." NED University Journal of Research, Thematic Issue On Energy, 2012.

[7] B. O. Agajelu, O. G. Ekwueme, N. S. P. Obuka, Gracefield O.R. Ikwu. "Life Cycle Cost Analysis of a Diesel/Photovoltaic Hybrid Power Generating System.” International Institute for Science Technology and Education (IISTE), Vol.3, No.1, 2013.

[8] T. James, A. Goodrich, M. Woodhouse, R. Margolis, S. Ong, "Building-Applied Photovoltaics (BAPV) in the Residential Sector: An Analysis of Installed Rooftop System Prices", National Renewable Energy Laboratory, Nov. 2011.

[9] A. M. Memari, L. D. Iulo, R. L. Solnosky, C. R. Stultz, "Building Integrated Photovoltaic Systems for Single Family Dwellings: Innovation Concepts," Open Journal of Civil Engineering, 2014: 102-119.

[10] S. Ziuku, E. L. Meyer. " Economic Viability of a Residential Building Integrated Photovoltaic Generator in South Africa." International Journal of Energy and Environment, Volume 3. Issue 6. 2012: 905-914.

[11] Viridian Solar Factory and Design Centre, Papworth, Cambridge, UK (2016. Des 21). 45 $\mathrm{kWp}$ Solar PV Installation for Commercial Building. [Online]. Available :http://www.viridiansolar.co.uk/Galleries/PV

[12] D. P. Sari, R. Nazir. "Optimalisasi Desain Sistem Pembangkit Listrik Tenaga Hybrid Diesel Generator-Photovoltaic Array Menggunakan Homer (Studi Kasus : Desa Sirilogui, Kabupaten Kepulauan Mentawai).” Jurnal Nasional Teknik Elektro, Maret 2015

[13] L. S. Mulia, M. Shidiq, Soeprapto. "Analisis Teknik dan Ekonomi Power Hibrida (Photovoltaic-PLN) di Jurusan Elektro Fakultas Teknik Brawijaya Malang." Jurnal Universitas Brawijaya, Vol 2, No. 7, 2014.

[14] M. S. Sree, S. Arunkumar, K. K. Murugavel. "Feasibility Study for the Net Metering 
Implementation in Residential Solar PV Installations across Tamil Nadu." International Conference On Computation Of Power, Energy, Information and Communication (ICCPETC). 2014. [15] Data Sheet Panel Surya Monocrystalline AE M6-48 Series 200W-225W 